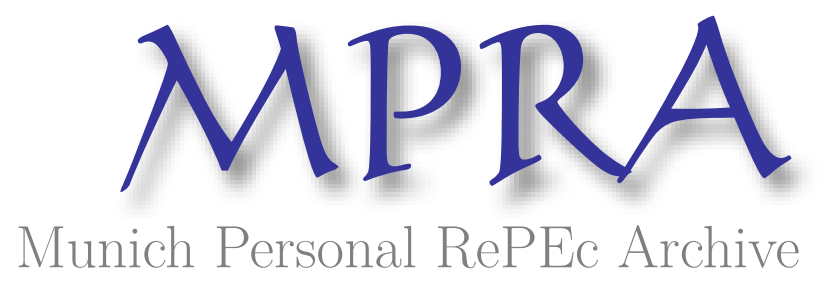

\title{
Financial inclusion in Nigeria: determinants, challenges and achievements
}

Ozili, Peterson K

March 2020

Online at https://mpra.ub.uni-muenchen.de/99173/

MPRA Paper No. 99173, posted 23 Mar 2020 03:08 UTC 


\title{
Financial inclusion in Nigeria: determinants, challenges and achievements
}

\author{
Peterson Ozili, Ph.D. \\ Central Bank of Nigeria
}

\begin{abstract}
This article analyse several indicators of financial inclusion in Nigeria. The findings reveal that people with at least a secondary education and unemployed people had higher levels of debit card ownership, higher levels of account ownership of any type, and higher levels of account ownership in a financial institution. Also, people with at least a secondary education had higher levels of borrowings from a bank or another type of financial institution, and had lower levels of savings at a financial institution. On the other hand, savings using a savings club or persons outside the family decreased among females, poor people and among people with a primary education or less. Furthermore, there were fewer credit card ownership by unemployed people while credit card ownership increased among employed people, the richest people and among people with at least a secondary education. Also, borrowings from family or friends decreased for most categories in 2014 and 2017. Finally, the econometric estimation shows that borrowings and savings outside financial institutions (using family, friends or saving clubs) significantly contributed to economic growth than borrowing and savings through financial institutions. The findings have implications.
\end{abstract}

JEL Code: G21, O16, P34

Keywords: financial inclusion, access to finance, financial exclusion, development, economic growth, poverty reduction, Nigeria, digital finance, cashless policy, financial education, financial literacy, Africa, robo advisor, regulatory sandbox

March, 2020.

The views expressed in this paper are those of the author and not necessarily the views of the management and Committee of Governors of the Central Bank of Nigeria. 


\section{Introduction}

Financial inclusion is a growing concern in Nigeria. The banking system in Nigeria is less inclusive than those in more developed African countries such as South Africa. In recent years, several policies have been introduced by various government agencies to increase the level of financial inclusion in Nigeria. The objective of this paper is to examine the determinants of financial inclusion in Nigeria. This paper also discusses the main barriers to financial inclusion in Nigeria and the progress made so far. In Nigeria, there is still a lack of proper understanding of what constitutes financial inclusion in Nigeria - Africa's second largest economy, where the process of financial reforms and liberalization is still ongoing. In fact, the importance of financial inclusion in Nigeria is determined by its connection to three major debates currently ongoing in the country that concern poverty reduction, the need to reduce the level of inflation level and the need to control the shadow banking sector.

Financial inclusion is defined as access to, and the use of, formal financial services to improve the welfare of individuals in a country (Demirgüç-Kunt et al, 2015, Ozili, 2020a\&b). Financial inclusion makes it possible for individuals to save for the future, invest in education, train their children, and launch businesses, and this contributes to poverty reduction and economic growth (Bruhn and Love, 2014; Ozili, 2018). In Nigeria, being financially included can lead to economic benefits as individuals with access to formal financial services are able to invest in education and entrepreneurial activities, which can contribute to reduce poverty and also allows them to increase their income (Ozili, 2020a; Bruhn \& Love, 2014). Recent studies in the literature have investigated financial inclusion in developing economies, but little attention has been paid on the determinants and challenges of financial inclusion in Nigeria. This paper aims to fill this gap by providing a comprehensive understanding of financial inclusion in Nigeria.

Using data from the World Bank's Global Findex database, the findings indicate that the educated, rich and employed population are more likely to be financially included than the poor, uneducated, and unemployed population. Also, borrowings and savings outside financial institutions (using family, friends or saving clubs) significantly contributed to economic growth than borrowing and savings through financial institutions.

This article contributes to the understanding of financial inclusion in Nigeria in two ways. Firstly, I analyse the determinants of financial inclusion, and make comments on which individual characteristics influence financial inclusion the most in Nigeria. Secondly, this study provides a more focused examination of the determinants of financial inclusion and use of financial services and products in Nigeria. To the best of my knowledge, there has been little research on the main challenges and determinants of financial inclusion in Nigeria. Thirdly, I analyze if and how barriers to financial inclusion and barriers to borrowing are associated with individual characteristics, including individuals' income and education. The answer to these questions can help us understand the current state of financial inclusion in Nigeria in order to identify policies that can promote financial inclusion. Four, as banks continue to grant fewer loans to ordinary people preferring to lend to corporations, this has led to growth in alternative sources of borrowing outside the formal financial sector, leading to the growth of the shadow banking system. The development of the shadow banking system raises questions concerning the effectiveness of banking regulation in Nigeria. Finally, the analysis of financial inclusion provides insights on the magnitude of the use of formal savings and credit from alternative sources of borrowing at the individual level in Nigeria and helps us in identifying the individual characteristics associated with reliance on different alternative sources of borrowing. 
The remainder of this article is structured as follows. Section 2 presents some stylized facts about financial inclusion in Nigeria. Section 3 presents the literature review on financial inclusion. Section 4 examine the impact of financial inclusion for economic growth. Section 5 concludes.

\section{Stylized facts about financial inclusion in Nigeria}

\subsection{Financial inclusion in Nigeria: trends and analysis}

This section highlights the major trends in the level of financial inclusion in Nigeria using eight (8) indicators of financial inclusion. Data was collected from the Global Findex database of the World bank. The data is based on the survey report of the World Bank on the state of financial inclusion in Nigeria. The survey requires respondents/individuals to give their opinion to specific questions over a $12 \mathrm{month}$ period. The eight categories (or indicators) of financial inclusion are: (i) owning an account of any type, (ii) borrowing from a financial institution, (iii) borrowing from family or friends, (iv) credit card ownership, (v) debit card ownership, (vi) account ownership in a financial institution, (vii) savings at a financial institution, and (viii) saved using a savings club or person outside the family.

\subsubsection{Account ownership of any type}

The 'account ownership of any type' category or indictor refers to the percentage of people who report having an account by themselves or together with someone else in a bank or at another financial institution. It also refers to people using a mobile money service as well. As can be observed in table 1, people with at least a secondary school education had higher levels of account ownership which includes owning an account in a bank, non-bank financial institution or a mobile money service. Similarly, people outside the labour force (i.e., unemployed people) had higher levels of account ownership including owning an account in a bank, other financial institution or a mobile money service. The other categories in table 1 witnessed an increase in account ownership in 2014 and a decline in 2017.

\begin{tabular}{|l|l|r|r|r|}
\hline & \multicolumn{1}{|c|}{ Table 1: Owning an account of any type } & \multicolumn{3}{|c|}{ Year } \\
\hline & \multicolumn{1}{|c|}{ People that report owning an account of any type } & 2011 & 2014 & 2017 \\
\hline 1 & Account owners (\% age 15+) & 29.7 & 44.4 & 39.7 \\
\hline 2 & Account owners, female (\% age 15+) & 25.9 & 34.0 & 27.3 \\
\hline 3 & Account owners, in labor force (\% age 15+) & 34.1 & 52.6 & 42.9 \\
\hline 4 & Account owners, income, poorest 40\% (\% ages 15+) & 13.9 & 30.5 & 24.5 \\
\hline 5 & Account owners, income, richest 60\% (\% ages 15+) & 40.1 & 53.7 & 49.7 \\
\hline 6 & Account owners, male (\% age 15+) & 33.2 & 54.3 & 51.4 \\
\hline 7 & Account owners, older adults (\% ages 25+) & 33.8 & 48.8 & 44.0 \\
\hline $\mathbf{8}$ & Account owners, out of labor force (\% age 15+) & $\mathbf{1 7 . 6}$ & $\mathbf{2 9 . 0 1}$ & $\mathbf{3 0 . 2}$ \\
\hline 9 & Account owners, primary education or less (\% ages 15+) & 23.2 & 28.1 & 16.1 \\
\hline 10 & Account owners, rural (\% age 15+) & 38.7 & 33.3 \\
\hline $\mathbf{1 1}$ & Account owners, secondary education or more (\% ages 15+) & $\mathbf{4 4 . 1}$ & $\mathbf{5 6 . 0}$ & $\mathbf{5 9 . 3}$ \\
\hline 12 & Account owners, young adults (\% ages 15-24) & 21.5 & 35.7 & 32.6 \\
\hline
\end{tabular}




\subsubsection{Borrowing from a financial institution}

The 'borrowing from a financial institution' category or indicator refers to the percentage of people who report borrowing any money from a bank or another type of financial institution. As can be observed in table 2, people with a secondary school education or higher education had higher levels of borrowings from a bank or another type of financial institution. Most of the other categories in table 2 witnessed an increase in account ownership in 2014 and a decline in 2017.

\begin{tabular}{|c|c|c|c|c|}
\hline & Table 2: Borrowing from a financial institution & \multicolumn{3}{|c|}{ Year } \\
\hline & People that report borrowing from a financial institution & 2011 & 2014 & 2017 \\
\hline 1 & Borrowed from a financial institution, female (\% age $15+)$ & 1.9 & 4.1 & 3.7 \\
\hline 2 & Borrowed from a financial institution, in labor force (\% age $15+)$ & 2.3 & 5.8 & 4.6 \\
\hline 3 & Borrowed from a financial institution, income, poorest $40 \%$ (\% age $15+)$ & 1.8 & 6.1 & 2.8 \\
\hline 4 & Borrowed from a financial institution, income, richest $60 \%$ (\% age $15+)$ & 2.3 & 4.7 & 4.7 \\
\hline 5 & Borrowed from a financial institution, male (\% age $15+)$ & 2.2 & 6.3 & 4.1 \\
\hline 6 & Borrowed from a financial institution, older adults (\% age $25+)$ & 2.0 & 5.7 & 3.8 \\
\hline 7 & Borrowed from a financial institution, out of labor force (\% age $15+)$ & 1.4 & 4.1 & 1.9 \\
\hline 8 & Borrowed from a financial institution, primary education or less (\% age $15+$ ) & 1.2 & 5.9 & 1.7 \\
\hline 9 & Borrowed from a financial institution, rural (\% age $15+)$ & 1.8 & 5.4 & 2.7 \\
\hline 10 & Borrowed from a financial institution, secondary education or more (\% age $15+$ ) & 2.8 & 4.8 & 5.9 \\
\hline 11 & Borrowed from a financial institution, young adults (\% age 15-24) & 2.1 & 4.4 & 4.3 \\
\hline
\end{tabular}

\subsubsection{Borrowing from family or friends}

The 'borrowing from a financial institution' category refers to the percentage of people who report borrowing any money from family, relatives, or friends. As can be observed in Table 3, borrowings from family or friends decreased in all categories in 2014 and 2017 except for the young adult category that had an increase in borrowings from family and friends in 2017.

\begin{tabular}{|l|l|r|r|r|}
\hline & \multicolumn{1}{|c|}{ Table 3: Borrowed from family or friends } & \multicolumn{3}{|c|}{ Year } \\
\hline & \multicolumn{1}{|c|}{ People that report borrowing money from family or friends } & 2011 & 2014 & 2017 \\
\hline $\mathbf{1}$ & Borrowed from family or friends (\% age 15+) & $\mathbf{4 4 . 1}$ & $\mathbf{3 7 . 5}$ & $\mathbf{2 8 . 2}$ \\
\hline $\mathbf{2}$ & Borrowed from family or friends, female (\% age 15+) & $\mathbf{4 2 . 2}$ & $\mathbf{3 7 . 2}$ & $\mathbf{2 7 . 8}$ \\
\hline $\mathbf{3}$ & Borrowed from family or friends, in labor force (\% age 15+) & $\mathbf{4 8 . 6}$ & $\mathbf{4 2 . 3}$ & $\mathbf{3 0 . 7}$ \\
\hline $\mathbf{4}$ & Borrowed from family or friends, income, poorest 40\% (\% age 15+) & $\mathbf{4 3 . 6}$ & $\mathbf{3 7 . 7}$ & $\mathbf{2 6 . 2}$ \\
\hline $\mathbf{5}$ & Borrowed from family or friends, income, richest 60\% (\% age 15+) & $\mathbf{4 4 . 3}$ & $\mathbf{3 7 . 4}$ & $\mathbf{2 9 . 5}$ \\
\hline $\mathbf{6}$ & Borrowed from family or friends, male (\% age 15+) & $\mathbf{4 5 . 9}$ & $\mathbf{3 7 . 8}$ & $\mathbf{2 8 . 7}$ \\
\hline $\mathbf{7}$ & Borrowed from family or friends, older adults (\% age 25+) & $\mathbf{4 7 . 8}$ & $\mathbf{4 2 . 2}$ & $\mathbf{2 6 . 6}$ \\
\hline $\mathbf{8}$ & Borrowed from family or friends, out of labor force (\% age 15+) & $\mathbf{3 1 . 8}$ & $\mathbf{2 8 . 5}$ & $\mathbf{2 1 . 1}$ \\
\hline $\mathbf{9}$ & Borrowed from family or friends, primary education or less (\% age 15+) & $\mathbf{4 6 . 1}$ & $\mathbf{4 4 . 6}$ & $\mathbf{2 6 . 8}$ \\
\hline 10 & Borrowed from family or friends, rural (\% age 15+) & $\mathbf{4 5 . 4}$ & $\mathbf{3 6 . 0}$ & $\mathbf{2 8 . 7}$ \\
\hline $\mathbf{1 1}$ & Borrowed from family or friends, secondary education or more (\% age 15+) & $\mathbf{4 2 . 3}$ & $\mathbf{3 2 . 5}$ & $\mathbf{3 0 . 3}$ \\
\hline 12 & Borrowed from family or friends, young adults (\% age 15-24) & 36.5 & 28.1 & 31.8 \\
\hline
\end{tabular}




\subsubsection{Credit Card Ownership}

The 'credit card ownership' category refers to the percentage of people who report having a credit card. As can be observed in table 4, credit card ownership by unemployed people decreased in 2014 and 2017. However, credit card ownership increased in 2014 and 2017 among employed people, the richest people and among people with at least a secondary education.

\begin{tabular}{|l|l|r|r|r|}
\hline & \multicolumn{1}{|c|}{ Table 4: Credit card ownership } & \multicolumn{3}{|c|}{ Year } \\
\hline & \multicolumn{1}{|c|}{ People who report owning a credit card } & 2014 & 2011 & 2017 \\
\hline 1 & Credit card ownership (\% age 15+) & 0.7 & 2.7 & 2.5 \\
\hline 2 & Credit card ownership, female (\% age 15+) & 0.8 & 1.7 & 1.7 \\
\hline $\mathbf{3}$ & Credit card ownership, in labor force (\% age 15+) & $\mathbf{0 . 9}$ & $\mathbf{2 . 5}$ & $\mathbf{3 . 1}$ \\
\hline 4 & Credit card ownership, income, poorest 40\% (\% age 15+) & 0.7 & 1.4 & 0.7 \\
\hline $\mathbf{5}$ & Credit card ownership, income, richest 60\% (\% age 15+) & 0.8 & $\mathbf{3 . 6}$ & $\mathbf{3 . 8}$ \\
\hline 6 & Credit card ownership, male (\% age 15+) & 0.9 & 3.7 & 3.4 \\
\hline 7 & Credit card ownership, older adults (\% age 25+) & $\mathbf{0 . 4}$ & $\mathbf{3 . 3}$ & $\mathbf{0 . 9}$ \\
\hline $\mathbf{8}$ & Credit card ownership, out of labor force (\% age 15+) & 0.5 & 2.2 & 0.1 \\
\hline 9 & Credit card ownership, primary education or less (\% age 15+) & 0.7 & 1.7 & 1.7 \\
\hline 10 & Credit card ownership, rural (\% age 15+) & $\mathbf{0 . 9}$ & $\mathbf{3 . 1}$ & $\mathbf{4 . 5}$ \\
\hline $\mathbf{1 1}$ & Credit card ownership, secondary education or more (\% age 15+) & 0.5 & 2.03 & 1.8 \\
\hline 12 & Credit card ownership, young adults (\% age 15-24) & &
\end{tabular}

\subsubsection{Debit card ownership}

The 'debit card ownership' category refers to the percentage of people who report having a debit card. As can be observed in table 5, debit card ownership increased in 2014 and 2017 among unemployed people and among people with at least a secondary education.

\begin{tabular}{|l|l|r|r|r|}
\hline & \multicolumn{1}{|c|}{ Table 5: Debit card ownership } & \multicolumn{3}{c|}{ Year } \\
\hline & \multicolumn{1}{|c|}{ People that report owning a debit card } & 2011 & 2014 & 2017 \\
\hline 1 & Debit card ownership (\% age 15+) & 18.5 & 35.6 & 31.5 \\
\hline 2 & Debit card ownership, female (\% age 15+) & 17.8 & 25.2 & 22.5 \\
\hline 3 & Debit card ownership, in labor force (\% age 15+) & 21.3 & 43.6 & 34.1 \\
\hline 4 & Debit card ownership, income, poorest 40\% (\% age 15+) & 6.5 & 22.5 & 19.6 \\
\hline 5 & Debit card ownership, income, richest 60\% (\% age 15+) & 26.5 & 44.3 & 39.4 \\
\hline 6 & Debit card ownership, male (\% age 15+) & 19.3 & 45.4 & 40.1 \\
\hline 7 & Debit card ownership, older adults (\% age 25+) & 20.6 & 39.3 & 35.6 \\
\hline $\mathbf{8}$ & Debit card ownership, out of labor force (\% age 15+) & $\mathbf{1 1 . 1}$ & $\mathbf{2 0 . 4}$ & $\mathbf{2 3 . 9}$ \\
\hline 9 & Debit card ownership, primary education or less (\% age 15+) & 4.1 & 18.1 & 9.6 \\
\hline 10 & Debit card ownership, rural (\% age 15+) & $\mathbf{3 0 . 5}$ & $\mathbf{4 8 . 0}$ & $\mathbf{4 9 . 5}$ \\
\hline $\mathbf{1 1}$ & Debit card ownership, secondary education or more (\% age 15+) & 14.5 & 28.1 & 25.1 \\
\hline 12 & Debit card ownership, young adults (\% age 15-24) & & \\
\hline
\end{tabular}




\subsubsection{Account ownership in a financial institution}

The 'account ownership in a financial institution' refers to people who report having an account (by themselves or together with someone else) at a bank or another type of financial institution but not in a mobile money service. As can be observed in Table 6, account ownership in a financial institution increased in 2014 and 2017 among unemployed people and among people with at least a secondary education.

\begin{tabular}{|l|l|r|r|r|}
\hline & \multicolumn{2}{|c|}{ Table 6: Account ownership in a financial institution } & \multicolumn{3}{c|}{ Year } \\
\hline & \multicolumn{1}{|c|}{ Persons that report owning an account in a financial institution } & 2011 & 2014 & 2017 \\
\hline 1 & Financial institution account (\% age 15+) & 29.6 & 44.1 & 39.4 \\
\hline 2 & Financial institution account, in labor force(\% age 15+) & 34.1 & 52.5 & 42.6 \\
\hline 3 & Financial institution account, older adults(\% age 25+) & 33.8 & 48.4 & 43.8 \\
\hline $\mathbf{4}$ & Financial institution account, out of labor force (\% age 15+) & $\mathbf{1 7 . 6}$ & $\mathbf{2 8 . 3}$ & $\mathbf{3 0 . 2}$ \\
\hline 5 & Financial institution account, primary education or less(\% age 15+) & 12.2 & 27.5 & 15.8 \\
\hline 6 & Financial institution account, rural(\% age 15+) & 23.5 & 38.4 & 33.1 \\
\hline $\mathbf{7}$ & Financial institution account, secondary education or more(\% age 15+) & $\mathbf{4 4 . 1}$ & $\mathbf{5 5 . 9}$ & $\mathbf{5 8 . 9}$ \\
\hline 8 & Financial institution account, female(\% age 15+) & 25.9 & 33.5 & 27.1 \\
\hline 9 & Financial institution account, income (poorest 40\%; \% age 15+) & 13.9 & 29.9 & 24.5 \\
\hline 10 & Financial institution account, income (richest 60\%; \% age 15+) & 40.1 & 53.6 & 49.2 \\
\hline 11 & Financial institution account, male(\% age 15+) & 33.2 & 54.2 & 51.7 \\
\hline 12 & Financial institution account, young adults(\% age 15-24) & 21.4 & 35.7 & 32.1 \\
\hline
\end{tabular}

\subsubsection{Saved at a financial institution}

The 'saved at a financial institution' category refers to the percentage of people who report saving or setting aside any money at a bank or another type of financial institution for the purpose of savings. As can be observed in table 7, savings at a financial institution decreased in 2014 and 2017 among people with at least a secondary education.

\begin{tabular}{|l|l|r|r|r|}
\hline & \multicolumn{1}{|c|}{ Table 7: Saved at a financial institutions } & \multicolumn{3}{c|}{ Year } \\
\hline & \multicolumn{1}{|c|}{ Persons that report having savings at a financial institution } & 2011 & 2014 & 2017 \\
\hline 1 & Saved at a financial institution (\% age 15+) & 23.5 & 27.1 & 20.6 \\
\hline 2 & Saved at a financial institution, out of labor force (\% age 15+) & 11.9 & 13.7 & 12.3 \\
\hline 3 & Saved at a financial institution, female (\% age 15+) & 20.9 & 21.4 & 13.4 \\
\hline 4 & Saved at a financial institution, in labor force (\% age 15+) & 27.8 & 34.1 & 23.4 \\
\hline 5 & Saved at a financial institution, income, poorest 40\% (\% age 15+) & 9.5 & 17.8 & 13.3 \\
\hline 6 & Saved at a financial institution, income, richest 60\% (\% age 15+) & 32.9 & 33.1 & 25.3 \\
\hline 7 & Saved at a financial institution, male (\% age 15+) & 26.2 & 32.4 & 27.2 \\
\hline 8 & Saved at a financial institution, older adults (\% age 25+) & 26.7 & 30.5 & 22.0 \\
\hline 9 & Saved at a financial institution, primary education or less(\% age 15+) & 8.2 & 17.5 & 7.5 \\
\hline 10 & Saved at a financial institution, rural (\% age 15+) & 18.7 & 24.5 & 17.2 \\
\hline 11 & Saved at a financial institution, secondary education or more (\% age 15+) & $\mathbf{3 6 . 3}$ & $\mathbf{3 3 . 6}$ & $\mathbf{3 1 . 2}$ \\
\hline 12 & Saved at a financial institution, young adults (\% age 15-24) & 17.2 & 20.0 & 18.5 \\
\hline
\end{tabular}




\subsubsection{Saved using a savings club or person outside the family}

The 'saved using a savings club or person outside the family' category refers to the percentage of people who report saving or setting aside any money to start, operate, or expand a farm or business, young adults. As can be observed in Table 8, savings using a savings club or person outside the family decreased in 2014 and 2017 among females, poor people, people with a primary education or less.

\begin{tabular}{|l|l|r|r|r|}
\hline & Table 8: Saved using a savings club or person outside the family & \multicolumn{3}{|c|}{ Year } \\
\hline & People using a savings club or a person outside the family to save & 2011 & 2014 & 2017 \\
\hline 1 & Saved, (\% age 15+) & 44.4 & 23.0 & 25.4 \\
\hline 2 & Saved, in labor force(\% age 15+) & 48.6 & 27.1 & 28.7 \\
\hline $\mathbf{3}$ & Saved, female (\% age 15+) & $\mathbf{4 7 . 1}$ & $\mathbf{2 5 . 1}$ & $\mathbf{2 4 . 7}$ \\
\hline $\mathbf{4}$ & Saved, income, poorest 40\%(\% age 15+) & $\mathbf{4 4 . 2}$ & $\mathbf{3 0 . 6}$ & $\mathbf{2 3 . 3}$ \\
\hline 5 & Saved, income, richest 60\% (\% age 15+) & 44.6 & 17.9 & 26.7 \\
\hline 6 & Saved, male (\% age 15+) & 41.9 & 21.1 & 25.9 \\
\hline 7 & Saved, older adults (\% age 25+) & 48.8 & 26.3 & 27.8 \\
\hline 8 & Saved, out of labor force (\% age 15+) & 33.1 & 15.34 & 15.7 \\
\hline $\mathbf{9}$ & Saved, primary education or less (\% age 15+) & $\mathbf{4 8 . 6}$ & $\mathbf{3 0 . 1}$ & $\mathbf{2 3 . 9}$ \\
\hline 10 & Saved, rural (\% age 15+) & 44.8 & 22.9 & 23.7 \\
\hline 11 & Saved, secondary education or more (\% age 15+) & 35.7 & 17.6 & 26.9 \\
\hline 12 & Saved, young adults (\% age 15-24) & & 20.4 \\
\hline
\end{tabular}

\subsection{Factors that promote financial inclusion in Nigeria}

\subsubsection{Fintech}

Fintech, or financial technology, refers to new or existing technology or innovation that disrupts traditional ways of conducting financial transactions. Fintech introduces a new way to perform financial transactions with little or no human interaction. Nigeria witnessed a boom of Fintech business in 2015 and this became possible through increase in the number of smartphone users across the country. Fintech, made available through the smartphone of individuals in Nigeria, made it possible for individuals to shop for goods at online stores, make bank transfers using mobile apps, manage their personal finance; thereby bringing a large number of citizens to the financial sector to take advantage of these benefits. Also, start-up businesses were able to set-up new business models that require business owners to work from home using financial technology and to save the cost of renting a physical office space. Also, through payment-based fintech processes, the financial regulator is able to monitor all financial transactions for transparency, fairness and to detect suspicious activities related to fraud and other crimes.

\subsubsection{Digital finance: USSD codes, electronic cards and mobile bank apps.}

A PWC 2017 Fintech survey report ${ }^{1}$ showed that over $62 \%$ of customers will use mobile applications to access financial services within the next 5 years in Nigeria. The introduction of USSD codes in Nigeria (such as GTB *737\#) allow customers to make a wide range of financial transactions from their phone

\footnotetext{
${ }^{1}$ https://www.pwc.com/ng/en/pdf/nigeria-fintech-report-2017.pdf
} 
using a USSD code. The USSD code is a communication technology that sends a request to a banking system interface on behalf of the bank customer with the expectation that the bank will approve the request when the correct access-code or passcode is provided. Electronic cards have also been in existence in Nigeria as far back in 2015 and have continued to evolve into sophisticated card products over time such as ATMs, dollar cards, etc. Also, there is wide use of debit cards in Nigeria. Mobile bank apps are also used by bank customers to access their bank accounts remotely and to authorize financial transactions from one party to another. These digital finance products have helped to increase the level of financial inclusion in Nigeria.

\subsubsection{Authority to reject or accept financial innovation by the financial regulator}

Another factor that helped to promote financial inclusion in Nigeria is the power of the financial sector regulator to accept or reject financial innovations from operating in Nigeria. The financial regulator, the Central Bank of Nigeria (CBN), is independent and has full power to reject or accept an application made by a company to introduce a financial innovation to the Nigerian financial sector. The CBN receive and assess all applications made by local and foreign companies seeking to introduce a new financial technology or new financial products and services in the Nigerian financial market. Ideally, the CBN will invite the promoters of the innovation for a discussion session, to ensure that the CBN understands what the innovation seeks to achieve and the associated risks. The CBN will then assess whether the new innovation is risky and whether the applicant-company can manage the risk internally, and whether the innovation will increase systemic risk to the entire financial system. Based on these criteria, the CBN will make an acceptreject decision. Therefore, promoters of certain financial innovations in Nigeria have a duty to ensure that the regulators understand what the innovation seeks to achieve and the associated risks, to improve the chance of getting the regulator's approval for it. Finally, it important to understand that all financial innovations that improves the level of financial inclusion in the country and which do not pose any significant risks to the financial system are more likely to be approved by the CBN.

\subsection{Areas for improvement}

\subsubsection{Securing digital payment technology}

The government in Nigeria needs to ensure that digital payment channels are safer, more affordable, and more transparent. Digitizing payments through technology can improve efficiency by increasing the speed of payments and reducing the cost of disbursing and receiving payments. It can also improve the security of payments and thus lower the incidence of payment fraud. Disbursing payments through digital channels rather than cash can increase financial transparency and reduce corruption.

\subsubsection{Greater empowerment of women}

Efforts aimed at increasing the level of financial inclusion in Nigeria should ensure that women are granted substantial access to formal financial services. Inclusive growth is meaningless without including women who are often marginalised in the society. Excluding women, who represent half the population, makes the financial development process and outcomes unjust, unacceptable and incomplete. 


\subsubsection{Greater possibilities for Fintech}

Currently, the activities of Fintech in Nigeria is rudimentary. There are greater possibilities and ideas that can be achieved through Fintech if they are allowed to operate to their full potential. Fintech can revolutionize how existing financial institutions create and deliver products and services and can provide new gateways for business owners to grow their business. Fintech can also help to decentralize or democratize access to financial services in Nigeria. Examples of these possibilities or ideas include: the use of cryptocurrencies, blockchain, new digital advisory systems, digital advisory trading systems, artificial intelligence, machine learning, electronic peer-to-peer lending, equity crowdfunding and mobile payment services. Nigeria also need to introduce robotic advisory systems that provide personalized individual assistance in the management of personal finance. Fintech can provide automated financial advisors, also known as 'robo-advisors'. Currently, the United States is the leading market for robo-advisors. The roboadvisors can reduce fixed costs (such as the labour cost of hiring financial advisors or the cost of renting a physical office space), and robo-advisors can also help to reduce transaction fees.

\subsubsection{Financial literacy training}

There is a need for greater training for financial literacy in the country particularly in the Northern part of Nigeria. Beneficiaries of financial literacy training will be willing to own an account and will be more likely to save. Female beneficiaries of financial literacy will also be able to use credit to start their own businesses to improve their welfare and the welfare of their families. Nigeria can strengthen financial literacy training to close the financial inclusion gap in the country.

\subsubsection{Create regulatory sandbox for financial innovation}

Nigeria faces some challenge in regulating Fintech and financial innovations. Some of these challenges include: the lack of adequate resources, staff, expertise, and tools for regulation; the underdeveloped financial market infrastructure, limited market for retail financial services; balancing consumer protection and competition in the financial innovation industry, insufficient regulatory ability to adapt to the fastchanging digital finance and financial technology environment; etc. These regulatory challenges in regulating financial innovation in Nigeria can be overcome by creating regulatory sandbox for financial innovation. A regulatory sandbox is a framework set up by a financial sector regulator to test innovations and to allow innovations to thrive in a controlled environment under the regulator's supervision. Regulatory sandboxes can help to address some of these challenges in the following way: (i) by eliminating existing regulations that hinder the existing financial innovation, (ii) by enabling the regulator to revise and shape regulatory and supervisory policies to ensure that the policies favour the growth of fintech and financial innovations, (iii) by creating an open and active dialogue between regulators and innovative service providers so that each side can learn from the other. Nigeria need to create regulatory sandboxes that allow financial innovations to thrive for the benefit of excluded and underserved customers. 


\section{Literature review}

\subsection{Nigerian studies}

Few studies have examined some determinants of financial inclusion in Nigeria. For instance, Bayero (2015) find that greater awareness by customers and good financial infrastructure had positive effects for financial inclusion. Babajide et al (2015) show that financial inclusion is a significant determinant of the total factor of production in the economy. Mbutor and Uba (2013) examine the effect of financial inclusion on monetary policy in Nigeria between 1980 and 2012. They find that the increasing number of bank branches does not lead to greater financial inclusion possibly because banks mainly pursued profit objective not financial inclusion objective when they open new bank branches. David-West (2016) explores Nigeria's path to digital financial inclusion and the use of Firstmonie - the mobile money app of First Bank to gain an understanding of the constraints of mobile money operations in Nigeria. Odior and Banuso (2012) show that a cashless policy is beneficial to the Nigerian economy. Efobi et al (2014) examined the determinants of access to, and use of, bank services in Nigeria using data from the World Bank Household Survey (2011) on financial inclusion. They examined three dependent variables: use of bank services, use of the account to save and frequency of bank withdrawals. They find that income level, age and ICT inclination of individuals affect access to and use of bank services in Nigeria. Nkwede (2015) investigate the effect of financial inclusion on the growth of Nigerian economy, and find that financial inclusion had a significant and negative impact on economic growth in Nigeria. Kama and Adigun (2013) showed that although some progress have been made to improve the level of financial inclusion in Nigeria, the major challenges to achieving full financial inclusion in Nigeria are low financial literacy, inadequate infrastructural facilities, weak financial technology used by financial institutions. Adeola and Evans (2017) examine the impact of financial inclusion and financial development on economic diversification in Nigeria during the 1981-2014 period. They find that financial inclusion, when measured in terms of financial access and financial usage, has positive and significant effects on economic diversification. Taken together, these studies show that Nigeria faces some challenges in achieving full financial inclusion, and there are mixed evidence on the effect of financial inclusion on the economy.

\subsection{Barriers to financial inclusion in Nigeria}

\subsubsection{Political interference}

Several attempts by the financial system regulator (Central Bank of Nigeria, CBN) to implement certain financial inclusion policies in the country have been blocked by lawmakers both in the past and recently. This prevents the country from achieving its national financial inclusion goals. Recently, on the $18^{\text {th }}$ of September 2019, the CBN issued a cashless policy that imposed charges on withdrawals and deposits (see Table 9). The purpose of the CBN's cashless policy was to encourage electronic financial transactions through online bank transfers and to strongly discourage cash-based transactions which will help reduce theft, robbery and corruption. This policy will also compel employers and business owners to ensure that their employees own a bank account for payment of salaries electronically, and will make families compel their loved ones to own a bank account to facilitate online transfers of money to their loved ones. But the general public misunderstood the purpose of the policy, and reacted to the cashless policy. In response, the Nigerian lawmakers argued that the policy was not needed at this time, they argued that the rates were too high and that the implementation was discriminatory because it was implemented in some Nigerian states while other states where exempted, which undermined the equality of all Nigerian states in the country 
according to the Federal constitution. Due to these concerns, the Nigerian lawmakers stopped the CBN's effort to implement this aspect of its cashless policy ${ }^{2}$ at the time. This is an example of how political interference in Nigeria prevents achieving full financial inclusion.

\begin{tabular}{|l|l|l|l|}
\hline \multicolumn{4}{|c|}{ Table 9: Implementation of the CBN cashless policy } \\
\hline Account type & $\begin{array}{l}\text { Withdrawal/deposit } \\
\text { Limits }\end{array}$ & $\begin{array}{l}\text { Processing fees for } \\
\text { withdrawals }\end{array}$ & $\begin{array}{l}\text { Processing fees for } \\
\text { deposits }\end{array}$ \\
\hline Individual & Above N500,000 & $3 \%$ & $2 \%$ \\
\hline Corporate & Above N3,000,000 & $5 \%$ & $3 \%$ \\
\hline Implementation date & $18^{\text {th }}$ September 2019 \\
\hline Pilot state & Lagos, Ogun, Kano, Abia, Anambra, Rivers and the FCT \\
\hline
\end{tabular}

\subsubsection{High cost of doing business}

The cost of doing business in Nigeria is high for many reasons. Unreliable power supply, high cost of energy, insufficient credit bureaus, and the absence of a national database with customers' financial history, all these contribute to increasing the cost of doing business in Nigeria. Nigerian banks also design the pricing of their financial products and services to reflect the prevailing cost of doing business in the country which leads to high interest rates on loan and high transaction costs. As a result, individuals are often discouraged from borrowing from banks preferring to borrow from family, friends and from agents in the informal sector, and this will reduce the level of financial inclusion. Also, high transaction costs might be too costly for small businesses and banks may lose the patronage of small businesses, which would have negative effects for financial inclusion.

\subsubsection{Uneven financial development in the North and South regions}

Most financial institutions and Fintech businesses are located in the South region of the country because the South region has better infrastructure and high level of business patronage. Financial institutions in the South offer financial services at competitive rates to individuals and businesses which leads to intense competition for market share through innovation and great customer service. These leads to higher levels of financial development in the South region, compared to the North. Also, it is easier for financial institution to persuade southerners to open bank accounts in a bank to take advantage of interest on deposits, free debit cards and digital banking apps due to high financial literacy in the South. In contrast, the North is relatively financially underdeveloped because financial institutions have fewer presence in the North region due to low business patronage, lack of infrastructure in some areas and weak infrastructure in other areas in the North region. Also, it is not easy for financial institution to persuade uneducated Northerners to open bank accounts in a bank so that they can take advantage of interest on deposits, free debit cards, digital banking apps, etc, due to religious sentiments and other belief systems that are anti-technology in the region. These issues affect the level of financial inclusion in the North of Nigeria.

\footnotetext{
2 https://punchng.com/cashless-policy-reps-ask-cbn-to-suspend-charges-on-deposits/ http://saharareporters.com/2019/09/19/breaking-suspend-new-charges-transaction-lawmakers-tell-cbn
} 


\subsubsection{High financial illiteracy}

The lack of financial education programs has been a problem that many individuals and families face in Nigeria. Lack of knowledge about available financial services makes it difficult for individuals and families to use emerging financial products and services to improve their financial welfare. And even when some financial education programs are implemented in urban cities, such programs are short-lived due to high cost especially when the costs of financial education programs outweigh its potential benefits. Some research show that the cost of financial education may outweigh its benefit (Willis, 2008; Ozili 2018). Also, it is important to point out that not all financial education programs are equally effective in Nigeria due to language barriers and the unwillingness of financial educators to go to remote areas to educate citizens in remote areas of the country. Thirdly, there is a lack of standard for financial literacy in Nigeria. This makes it difficult for financial educators to know if they have succeeded in teaching citizens about the use of financial services since there are no uniform standards for financial literacy in the country. If the goal of financial education is to increase financial literacy, how do financial educators in Nigeria know if they have succeeded without a standard financial literacy measure? Finally, financial education in Nigeria is not welltailored to meet the education needs of people in different demographics, life stages and learning styles in the country.

\subsubsection{The state of the economy}

In Nigeria, the state of the economy affects the level of financial inclusion. During recessions, the level of local economic activities decreases and give rise to unemployment in Nigeria which translates to financial hardship coupled with bank's unwillingness to lend to ordinary people during recessions. Individuals are forced to look away from banks and turn to family, friends and relatives for financial assistance during recessions. When recessions become severe, many individuals may withdraw their savings from formal financial institution preferring to hold their money themselves due to fear that banks might go bankrupt. Even the money borrowed from family and friends will not be used to revive local economic activities rather it will be used to finance emergency and personal consumption or expenditure during a recession, also, the savings withdrawn from banks might be hoarded and kept out of the financial system for a long time. All these leads to voluntary financial exclusion - where people choose to leave the financial sector because it has no benefit to them. This suggest that the level of financial inclusion is greater in periods of economic prosperity and lower during recessions.

\subsubsection{Corruption}

The public funds allocated for financial inclusion programs and activities in Nigeria may be used for other purposes contrary to what funds were allocated for. Such funds after been allocated may even be depleted at the allocation stage even before they reach the agency of the government responsible for achieving specific financial inclusion objectives. The remaining funds may be insufficient to achieve the desired financial inclusion objectives of the government. This demonstrates how corruption affects the level of financial inclusion in Nigeria. 


\subsubsection{Fintech increases discrimination}

Finrech lenders in Nigeria serve more creditworthy borrowers than poor people. They charge higher interest rates (above 20\%), but the higher interest paid to Fintech lenders by borrower is a result of the convenience provided by them. Finrech lenders are also discriminatory in charging higher interest rates from minority groups.

\section{Effect of financial inclusion on economic growth}

In section 6, several studies reported conflicting effect of financial inclusion on the Nigerian economy. I test this effect, using data collected from the Global Findex database of the World bank for the 2011, 2014 and 2017 period (note that financial inclusion data was only available for three years in the database). I empirically address the question: through what channel does greater financial inclusion lead to economic growth? To answer this question empirically, I break down the 'financial inclusion' variable into its several components, and I estimate economic growth as a function of financial inclusion as shown below:

GDP growth $=\mathrm{f}$ (financial inclusion determinants)

Econometrically, the model is expressed as:

$$
\Delta G D P t=A A t+C C t+D D t+E E t+F F t+G G t+H H t+e
$$

Where, $\mathrm{AA}=$ account owners of any type $(\%$ age $15+) ; \mathrm{CC}=$ borrowing from family or friends ( $\%$ age $15+)$; DD = credit card ownership (\% age 15+); $\mathrm{EE}=$ debit card ownership (\% age 15+); $\mathrm{FF}=$ financial institution account ownership (\% age 15+); GG = savings at a financial institution (\% age $15+) ; \mathrm{HH}=$ savings using a savings club or person outside the family $(\%$ age $15+)$, and $t=$ year.

The results in Table 10 show that only two financial inclusion indicators had a significant and positive effect on economic growth. The two indicators are the 'borrowing from family or friends' indicator and the 'saving using a savings club or person outside the family' indicator. The other variables were not significantly related to $\triangle \mathrm{GDP}$ and the models report a negative R-square. The result suggests that borrowings and savings outside financial institutions (using family, friends or saving clubs) significantly contributed to economic growth than borrowing and savings through financial institutions.

\begin{tabular}{|c|c|c|c|c|c|c|c|}
\hline \multicolumn{8}{|c|}{ Table 10: Effect of financial inclusion on economic erowth } \\
\hline & $\begin{array}{l}\text { Coefficient } \\
\text { (t-statistic) }\end{array}$ & $\begin{array}{l}\text { Coefficient } \\
\text { (t-statistic) }\end{array}$ & $\begin{array}{l}\text { Coefficient } \\
\text { (t-statistic) }\end{array}$ & $\begin{array}{l}\text { Coefficient } \\
\text { (t-statistic) }\end{array}$ & $\begin{array}{l}\text { Coefficient } \\
\text { (t-statistic) }\end{array}$ & $\begin{array}{l}\text { Coefficient } \\
\text { (t-statistic) }\end{array}$ & $\begin{array}{l}\text { Coefficient } \\
\text { (t-statistic) }\end{array}$ \\
\hline AA & $\begin{array}{l}0.106 \\
(2.30)\end{array}$ & & & & & & \\
\hline $\mathrm{CC}$ & & $\begin{array}{c}0.119 * \\
(3.44)\end{array}$ & & & & & \\
\hline DD & & & $\begin{array}{l}1.623 \\
(1.52)\end{array}$ & & & & \\
\hline $\mathrm{EE}$ & & & & $\begin{array}{l}0.134 \\
(2.06)\end{array}$ & & & \\
\hline FF & & & & & 0.107 & & \\
\hline
\end{tabular}




\begin{tabular}{|c|c|c|c|c|c|c|c|}
\hline & & & & & $(2.30)$ & & \\
\hline$\overline{G G}$ & & & & & & $\begin{array}{l}0.134 \\
(2.06)\end{array}$ & \\
\hline $\mathrm{HH}$ & & & & & & & $\begin{array}{c}0.183^{*} \\
(3.13)\end{array}$ \\
\hline R-square & -9.44 & 42.29 & -84.38 & -28.2 & -0.090 & -0.28 & 32.38 \\
\hline \multicolumn{8}{|c|}{$\begin{array}{l}\text { The regression is estimated using time series OLS regression. } \mathrm{AA}=\text { account owners of any type; } \mathrm{CC}= \\
\text { borrowed from family or friends; } \mathrm{DD}=\text { credit card ownership; } \mathrm{EE}=\text { debit card ownership; } \mathrm{FF}=\text { financial } \\
\text { institution account ownership; } \mathrm{GG}=\text { saved at a financial institution; } \mathrm{HH}=\text { saved using a savings club or person } \\
\text { outside the family. } * * *, * * * \text { denotes } 10 \%, 5 \% \text { and } 1 \% \text { significance levels. T-statistics are reported in } \\
\text { parenthesis. }\end{array}$} \\
\hline
\end{tabular}

\section{Conclusion}

There is the expectation that financial inclusion in Nigeria will contribute to economic growth by increasing the possibilities for greater savings, consumption, better education and entrepreneurship among individuals particularly female adults. In this paper, I analysed the state of financial inclusion in Nigeria based on the Global Findex database. I analysed several indicators of financial inclusion, and find that people with at least a secondary education and unemployed people had higher levels of debit card ownership, higher levels of account ownership of any type, and higher levels of account ownership in a financial institution.

Also, people with at least a secondary education had higher levels of borrowings from a bank or another type of financial institution, and had lower levels of savings at a financial institution. On the other hand, savings using a savings club or persons outside the family decreased among females, poor people and among people with a primary education or less. Furthermore, there were fewer credit card ownership by unemployed people while credit card ownership increased among employed people, the richest people and among people with at least a secondary education. Also, borrowings from family or friends decreased for most categories in 2014 and 2017. Finally, the econometric estimation shows that borrowings and savings outside financial institutions (using family, friends or saving clubs) significantly contributed to economic growth than borrowing and savings through financial institutions.

The main conclusion is that the level of financial inclusion in Nigeria is high relative to other African countries. However, the use of financial institutions to save in Nigeria remains low, which might be a result of lack of trust in financial institutions in Nigeria. The findings have some policy implications. It shows that, although financial inclusion does not constitute a major problem in Nigeria, Nigerian authorities should increase the number of formal account ownership by removing obstacles such as income and education bias and gender discrimination in the delivery and use of financial services. Nigerian policymakers should implement policy measures to expand the use of formal bank accounts for savings and borrowings by ordinary people. Future studies can explore the strategies that banks and financial institutions use to persuade individuals to save their money in banks as well as the strategies used by banks to encourage individuals to borrow money from banks and other financial institutions. 


\section{Reference}

Adeola, O., \& Evans, O. (2017). Financial inclusion, financial development, and economic diversification in Nigeria. The Journal of Developing Areas, 51(3), 1-15.

Babajide, A. A., Adegboye, F. B., \& Omankhanlen, A. E. (2015). Financial inclusion and economic growth in Nigeria. International Journal of Economics and Financial Issues, 5(3), 629-637.

Bayero, M. A. (2015). Effects of Cashless Economy Policy on financial inclusion in Nigeria: An exploratory study. Procedia-Social and Behavioral Sciences, 172, 49-56.

Bruhn, M., \& Love, I. (2014). The real impact of improved access to finance: Evidence from mexico. Journal of Finance, 69(3), 1347-1376.

David-West, O. (2016). The path to digital financial inclusion in Nigeria: Experiences of Firstmonie. Journal of Payments Strategy \& Systems, 9(4), 256-273.

Demirgüç-Kunt, A., Klapper, L., Singer, D., \& Van Oudheusden, P. (2015). The Global Findex Database 2014: Measuring Financial Inclusion around the World. World Bank Policy Research Working Paper 7255, (April), 1-88. https://doi.org/10.1596/1813-9450-7255.

Efobi, U., Beecroft, I., \& Osabuohien, E. (2014). Access to and use of bank services in Nigeria: Microeconometric evidence. Review of development finance, 4(2), 104-114.

Kama, U., \& Adigun, M. (2013). Financial Inclusion in Nigeria: The Journey so Far. Available at SSRN 2365209 .

Mbutor, M. O., \& Uba, I. A. (2013). The impact of financial inclusion on monetary policy in Nigeria. Journal of Economics and International Finance, 5(8), 318-326.

Nkwede, F. (2015). Financial inclusion and economic growth in Africa: Insight from Nigeria. European Journal of Business and Management, 7(35), 71-80.

Odior, E. S., \& Banuso, F. B. (2012). Cashless banking in Nigeria: Challenges, benefits and policy implications. European Scientific Journal, 8(12).

Ozili, P. K. (2018). Impact of digital finance on financial inclusion and stability. Borsa Istanbul Review, 18(4), 329-340.

Ozili, P. K. (2020a). Financial inclusion research around the world: A review. Forum for Social Economics, 1-23).

Ozili, P. K. (2020b). Theories of Financial Inclusion. Available at SSRN 3526548.

Willis, L. E. (2008). Against financial-literacy education. Iowa L. Rev., 94, 197. 